\title{
The Setting of School-Enterprise Major Curriculum Based on Students' Satisfaction
}

\author{
Luan Qianqian*, Kong Linghan, Diao Jinling and Ramir Austria \\ University of the Cordilleras, Baguio, Philippines
}

\begin{tabular}{|c|c|}
\hline ARTICLE INFO & ABSTRACT \\
\hline $\begin{array}{l}\text { Keywords: } \\
\text { School-Enterprise } \\
\quad \text { Cooperation } \\
\text { Talent } \\
\text { Model } \\
\text { Cultivation }\end{array}$ & $\begin{array}{l}\text { The current curriculum cannot meet the needs of students for } \\
\text { learning and employment. In this study, the researchers shall } \\
\text { improve students' satisfaction with school-enterprise cooperation } \\
\text { specialty by optimizing the curriculum of school-enterprise } \\
\text { cooperation specialty. The article through the survey questionnaire } \\
\text { and the literature research method was carried on the analysis and } \\
\text { the discussion for this study. This provides an important } \\
\text { development direction for the school-enterprise cooperation } \\
\text { professional curriculum development. One the one hand, students } \\
\text { can master more practical skills. It can also improve the satisfaction } \\
\text { and success rate both school and enterprise, and promote long-term } \\
\text { and stable cooperative relationship. To achieve a win-win situation } \\
\text { for schools, enterprises and students. }\end{array}$ \\
\hline
\end{tabular}

\section{Introduction}

Professional satisfaction is an important source of professional learning motivation for college students. It directly affects their learning and quality of life. It is their feeling and attitude towards professional learning activities. This feeling and attitude indicate the learner's likeness or desire for learning activities. Understanding the professional satisfaction of college students can not only show students' attitudes and inclinations towards school, but also reflect the quality of the school's training talents and the social needs of professional settings, as well as professional development and improvement direction.

The current school-enterprise cooperation majors mainly have the following problems: Students' recognition of the profession is not high; students lack practical practice in the learning process; the school-enterprise cooperation curriculum is unreasonable. Among these problems, whether the curriculum is reasonable is the main factor determining students' professional recognition. Through the investigation and study of the cooperation between the universities and enterprises in many universities, we found that the following problems exist in the setting of the school-enterprise cooperation professional courses: 1. Course setting is repeated. The basic subjects of the subject conflict with the basic content of some professional courses. 2. Content of the teacher's lecture is not clear. Some professional courses have different names, but the content of the courses is overlapping and repeated. 3 . Teachers lack vocational training. Most of the teachers who offer logistics majors for students lack research, teaching, and work experience in logistics. 4. Slow update of teaching content the setting of professional courses failed to make up for the shortage of the basic courses of the subject. In the classroom teaching and practical teaching of school-enterprise cooperation, a set of standardized and standardized experiences and systems have not yet been formed.

* Corresponding Author E-Mail Address: qianqianluan@126.com 
In order to truly achieve the knowledge and market needs to be zero distance, so that students can stand out in the tough competition after graduation, the best way is to let students adapt to market needs in advance. School-enterprise cooperation has shortened the way students get from school to society. Reasonable adjustment of the school-enterprise cooperation professional curriculum can make students' knowledge of the school and the social needs better. The purpose of the reform of the curriculum system is to lead the curriculum process with work tasks, to achieve an effective combination of theory, practice and work tasks, to significantly improve teaching quality and teaching efficiency, and to ensure that school teaching is more in line with the actual needs of enterprises that will meet student satisfaction. Ensuring the promotion of school-enterprise cooperation students' interest in learning, realizing the effective connection between their hands-on ability and corporate job requirements, cultivating their comprehensive ability and sustainable development ability, enhancing employment competitive advantage, and better meeting the needs of local economic industry enterprises.

\section{Review of Related Literature}

Customer satisfaction was first proposed by American scholar Cardozo in 1965, and research on customer satisfaction has continued for decades. In recent years, due to the influence of the concept of Total Quality Management (TQM) in the field of higher education, the education authorities have gradually realized that higher education is a service, and the role of student satisfaction in the quality assessment of higher education institutions has become increasingly prominent. College students' satisfaction with colleges and universities refers to the psychological feelings of students and their personal views on school work in the process of university students' study and life (Zhuxin, XuYuanhuo, 2015).

School-enterprise cooperation is an innovative form of higher education services, and students are the end consumers of this service industry (Guowenmao,2017). Students are also participants in teaching practice activities, and their satisfaction can reflect the advantages and disadvantages of practical teaching. How to improve satisfaction and play a positive role in improving the quality of teaching and cultivating outstanding talents (Weijiantao,2009). With the rapid expansion of the scale of colleges and universities, the competition among colleges and universities is becoming increasingly fierce. How to give full play to the characteristics and advantages of the cooperation between universities and enterprises in the university, and cultivate high-end skilled talents that are needed for the first line of production, construction, service and management for local economic development. The problem has become an important issue facing colleges and universities (Chenshujiao,2012). Therefore, "studentoriented", improving the quality of professional services, and thus improving professional satisfaction has become an important topic of professional development (Guodingqin,2008). In short, the school-enterprise cooperation profession should start from the satisfaction of college students on the professional curriculum, grasp the students' attitudes and inclinations towards professional learning, and thus promote professional development and improvement direction. There are some problems in the course design. Firstly, the orientation of the course is not accurate. In the course system, there are too many theoretical courses and too few practical courses (Zhaodanmei, 2016), the content of textbooks is outdated, lagging behind the current technology (Huangxiaofen, 2016), the phenomenon of emphasizing theory over practice is very common (Minhengfeng,2014). The second is to ignore the quality of the class into (Shixiaoying, 2018) the vocational course has become a pure vocational course, which greatly reduces the courses of students' physical training, psychological quality training, and the ability to grasp policies and regulations (Wangyi, 2018). This situation is very prominent in order to train (Shuwei, 2018). Thirdly, the curriculum of the school does not correspond to the positions of enterprises. The content of the course is not consistent with the use of the enterprise. The students cannot meet the requirements of the enterprise and must be retrained before they can 
take up the post. Therefore, school-enterprise cooperation should not only pay attention to the study of students' theoretical knowledge, but also pay attention to the improvement of students' practical ability, and combine the theory with the practical curriculum, so that students can have a comprehensive quality of sustainable development after entering the society.

School-enterprise cooperation is a process in which schools and enterprises participate in personnel training. Focusing on cultivating students' overall quality, comprehensive ability and employment competitiveness, using the educational environment and educational resources of schools and enterprises, classroom teaching and students participate in practical operations. Organically combine to cultivate the application talents that enterprises need (Luzhigao,2018). School-enterprise cooperation in running schools is the only way to develop the connotation of the school, and curriculum reform is the trend of the times. The content of teaching and teaching methods should be close to the actual needs of the cooperative enterprises (Bizhigao,2018). The curriculum system is the main carrier of university personnel training, and it is the bridge to realize the educational concept and the goal of talent training. Therefore, it is essential to build a curriculum system consistent with the orientation and goal of talent training (Taoning, 2018). School-enterprise cooperation professions should conduct extensive social research in the professional setting and determination of talent training specifications, and understand the information on talent needs of enterprises, industries and society, and opinions on personnel training specifications. Through the "order-based" professional courses, you can provide good knowledge for students' future career development and migration (Liyan, 2017). Therefore, the reform of the curriculum of school-enterprise cooperation is the general trend of the development of school-enterprise cooperation, and it is also an important measure to achieve high efficiency, students and enterprises.

\section{Methodology}

This paper uses empirical research methods, literature research methods, and interview methods. The empirical research method was used to analyze the cases of school-enterprise cooperation students' satisfaction in the current higher education. Furthermore, this study conducts in-depth analysis of some typical problems and draws the best course design. The review of literature was conducted on the design of school-enterprise cooperation courses in the digital resources of school libraries. Through the collection and collation of the schoolenterprise cooperation professional curriculum design, the research was able to analyze the multiple angles and levels of the curriculum. Interview was conducted to understand the psychology and behavior of the interviewee through face-to-face conversation between the interviewee and the interviewee. Through face to face interview with the students, the researchers were able to identify the students' real needs for their majors and whether they are satisfied with their majors and what they want to learn from their majors, so as to provide an objective basis for our curriculum reform.

\section{Results and Discussions}

Previous studies show that there are many problems in the current school-enterprise cooperation profession, especially in the curriculum setting. Students' satisfaction with the profession is the main criterion for measuring the success of the school-enterprise cooperation curriculum. Therefore, for the curriculum of the school-enterprise cooperation profession, we believe that the reforms are mainly from the following aspects:

First of all, the credit system should be implemented, and the students' theoretical study in the school and the practice in the enterprise should be introduced into the credit system. "Schoolenterprise cooperation" requires a flexible curriculum, which is embodied in diversity and selectivity. The credit system that supports the choice of diversified courses is implemented, so the "School-enterprise cooperation" profession should fully introduce the credit system. 
Students taking credits in the classroom and taking credits in business practice should be counted in the student's total credits. Secondly, the introduction of the credit system into the curriculum design, students can choose courses according to their own preferences and abilities, thus stimulating students' interest in learning. Give play to the main role of student learning. It also allows students to start a business, learn, or work while studying. Under the credit system and flexible academic system, the school's teaching organization and teaching mode will have a big change. The credit system can not only identify students' previous learning or work experience, but also realize mutual recognition and accumulation of credits across institutions. It should be noted that in addition to offering a variety of courses, the school-enterprise cooperation program should fully reflect the selective functions of the credit system and conduct comprehensive, full-time and full-time career guidance to help students learn to choose rationally.

Establish a practice-oriented curriculum model. The main characteristics of the "practiceoriented" curriculum model are: the division of work tasks as the main basis for the classification of curriculum categories; the starting point of the curriculum structure with the mastery of practical process and practical knowledge, so that students can get the work experience in the course of learning courses; Taking practical knowledge as the main body and organizing course content centering on work tasks; taking the practice process instead of book study as the main form of student learning, and using work samples to evaluate the results of student learning. The practice-oriented curriculum model emphasizes the active acquisition of educational models with emphasis on practice, socialism, and experience.

It is necessary to reform the teaching mode and establish a "mutually adaptable" orientation of the teaching model. It is necessary to maximize the adaptation and unification of the professional training objectives and local industrial structure, curriculum and job requirements, teacher and student needs, employment and business needs. Secondly, it is necessary to change the teaching concept of teachers and strengthen curriculum management. At the same time, establish a "practical-oriented" curriculum model management mechanism, carry out teacher training, and build a team of masters, and actively encourage young teachers to practice and further study in enterprises. Finally, carry out school-based research, develop textbooks that adapt to the "practice-oriented" curriculum model, and compile textbooks to follow the "practical process" and build a "technical knowledge" system.

Establish a modular curriculum system. The module teaching method is based on the premise of school-enterprise cooperation, and relies on the resources of the cooperative enterprise to carry out teaching work. According to the company's skill requirements for specific job positions, the course structure and teaching content are expressed in the form of module units with specific functions and applications, so that each module becomes a specific teaching unit. Generally speaking, this module the division can be carried out according to the company's workshop. The teaching process is organized around specific modules, with students as the main body and teachers as the mainstay. The teaching content covers basic theory, practical skills, cutting-edge knowledge, social needs, employment prospects, teamwork and so on. The teaching process includes theoretical knowledge teaching, task release, practical operation, technical exchange, and report summary. When designing the teaching module, the schoolenterprise cooperation profession should proceed from the overall teaching goal of the major or the course, and finally reach the teaching module of the teaching goal into several small modules, form the module chain and the module group, and complete the completion of one small module. Professional or course teaching objectives. For the setting and planning of the teaching module, it should be divided into two parts. The first is the public learning curriculum. The main part of this course is to improve the overall quality of students and to lay a solid foundation for students' humanities, professional quality, ethics, mathematics, foreign language communication and learning ability. The second is the professional study area course, which 
has the nature of "order". School-enterprise cooperation professions should conduct extensive social research in the professional setting and determination of talent training specifications, and understand the information on talent needs of enterprises, industries and society, and opinions on personnel training specifications. Through the "order-based" professional courses, students can provide good knowledge for future career development and migration.

\section{Conclusions}

The teaching under the cooperation of schools and enterprises is to integrate theoretical teaching with practical teaching on the basis of cooperation between schools and enterprises. Teachers should put theoretical knowledge into practice, let students do middle school, learn from the knowledge and skills acquired in practice. This can greatly stimulate the enthusiasm of students to learn and improve their interest in learning. Only by constantly adjusting the curriculum of the school-enterprise cooperation profession to improve students' enthusiasm for learning, can we give full play to the advantages of school-enterprise cooperation. On the basis of integrating the curriculum of different universities and school-enterprise cooperation, we propose the implementation of credit recognition system, establish a practice-oriented curriculum model, and establish a modular curriculum. It can fully stimulate students' interest in learning and promote the curriculum. However, in actual operation, due to the differences in the professional nature and actual situation of different universities and different schoolenterprise cooperation, other problems may be encountered in the curriculum, which requires us to find more in the future research. The universality and applicability of the solution strategy will ultimately enhance students' interest in learning and achieve a win-win situation for universities, enterprises and students.

\section{References:}

Bizhigao. (2018). Discussion on the Reform of Modular Curriculum System in Local Applied Colleges,Science teaching. 2, (40-41).

Chenshujiao (2012). Exploration of Constructing Teaching Mode Based on School-enterprise Cooperation.Continuing Education.10, (30-32).

Guodingqin (2008). Construction and Implementation of School-enterprise Cooperation Order Module under Credit System. Entrepreneur. 11, (140-141).

Guowenmao (2017) Research on the Evaluation Mechanism of School-enterprise Cooperation Accounting Talents under the Credit System Education Teaching Mode. Contemporary economy. 23, (104-106).

Huangxiaofen (2016). Research on the Reform and Improvement of Teaching Management in Colleges and Universities under the Credit System. Asia Pacific Education.1, (183-185).

Huronghua. (2017) Research on the Reform of Modular Course System of English Majors in Applied Undergraduate Colleges,Modern communication. 5, (121-127).

Liyan. (2017) Construction of modular curriculum system for e-commerce operation based on school-enterprise collaborative education,High teaching journal. 14, (31-33).

Luzhigao. (2018) Construction and Practice of 4+1 Modular Curriculum System for Higher Vocational Innovation and Entrepreneurship Education, Vocational and technical education. $5,(55-58)$.

Minhengfeng2014.Implementing the practice-oriented curriculum model in the form of company system. Journal of Mudanjiang College of Education. 13, (123-125). 
Shixiaoying (2018). Output-oriented innovation practice curriculum reform.Journal of Hangzhou Dianzi University. 1, (75-78).

Shuwei. (2018) Research on Modern Apprenticeship Modular Curriculum System in Vocational Education,Education and occupation.9,(101-105).

Taoning. (2018). Teaching Reform Practice of Knitting Module Course Based on SchoolEnterprise Cooperation Mode,Art and design. 9, (124-144).

Wangqiang. (2018). Analysis of the "wide platform, multi-directional" modular curriculum 20.system from the perspective of integration of production and education,Hubei Livestock Veterinary. 11, (44-46).

Wangyi.Preliminary(2018) Study on the Model of Curriculum Planning in School-Enterprise Cooperation.College Education.33, (124-126).

Weijiantao (2009). Analysis on the Reform of Higher Vocational Education Curriculum under the Condition of Credit System. Education and occupation.20, (126-127).

Zhangweirui. (2018). Teaching Exploration and Practice of Edible Mushroom School Enterprise Cooperation Module,Journal of microbiology. 5, (125-128).

Zhaodanmei (2016). On the Reform of Credit System and the Management System of Student Status in Colleges and Universities.Economist.5,(217-220).

Zhuxin,XuYuanhuo.(2015)Research on the Countermeasures to Improve the Reform of Credit System in Colleges and Universities.Journal of Jixi University.6,(51-52). 